\title{
The Dissipation of American Democracy in 2016: On the Emptiness of Elitism and the Poverty of Populism in the Trump Zone
}

Timothy W. Luke

In the contemporary capitalist global economy, as many of the authors in this issue of Fast Capitalism assert, markets have been remade by neoliberal leaders and organizations to favor greater global finance, manufacturing, and trade over preserving the prosperity of entire national economies. Under the blows of the austerity that such policies bring, democratic political hopes and cultural traditions are suffering new crises and shocks. From the Brexit vote in Great Britain, a hard-line party crackdown in China, and low intensity warfare with Russia in Ukraine to a failed coup in Turkey, a severe presidential crisis in Brazil, and the on-going fragmentation Syria in its brutal civil war, the struggles between ruling elites and restive mass publics are becoming more bitter and severe. In this respect, the United States plainly is no longer an exceptional country.

Indeed, as the 2016 presidential primaries for the Democratic and Republican parties in the United States of America have unfolded both at home and around the world, the crass culture of "reality TV" with its heated celebrations of extraordinary individual wealth, cruel competitive gamesmanship, and vicious spectacles of personal debasement simply to gain a bigger audience and dominate daily discussion incredibly has colonized the presidential elections in the USA. The centerpiece of this development is the bizarrely successful bid by Donald J. Trump to win the Republican Party nomination, which he captured during July 2016 despite widespread dissatisfaction in the party with this outcome. Trump's unique rhetorical mix of individual put-downs, suspiciously sweeping negative generalizations, anti-establishment insults, and xenophobic calls to greatness quickly have, in turn, become his campaign's most distinctive feature. While his bombast has started to stall going into the general campaign in August 2016, if only because of Trump's resolve to run as a Washington outsider and champion of "America First" policies, his over-the-line approach to electioneering continues to excite many alienated voters. Many political pundits are arguing that Trump also is driving away most moderate voters, and he is flagging in almost all of the swing states. Nonetheless, it is still over two weeks before Labor Day, and many electoral campaigns find new focus and energy as Election Day draws near.

Even so, one must return the decades before World War II to find equally extreme politicking in a major political party's campaign messaging and policy positioning. By praising Vladimir Putin's strong leadership, harping on President Obama's African heritage, ridiculing disabled reporters for their special needs, insulting female newscasters with sexist comments, doubting the geopolitical purposes of NATO, suggesting nuclear weapons would be used in the Middle East to defeat fundamentalist Islamic terrorists, hinting gun owners in defense of the Second Amendment "might do something" about Hilary Clinton to prevent her packing the Supreme Court with anti-gun justices, and claiming President Obama founded ISIS (the Islamic State of Iraq and Syria), Trump has pressed harder on his strangely twisted appeal to the darkest fears of the GOP party faithful by taking his gloomy vision into the national campaign. He unfortunately won too many primary elections by appearing seriously to regard myths as facts, facts 
as fictions, and previous administrations' policies (both Democratic and Republican) as evil government conspiracies aimed at destroying the good life for average ordinary Americans.

Coming on the heels of the Tea Party insurgency in 2010, many pundits and politicians are conceding that the USA is trapped within a new space of "post-factual politics," which is also at work in Russia's hybrid war over the Eastern Ukraine, the Brexit vote in Great Britain, and China's active annexation of rocky shoals in the South China Sea as parts of its homeland. While post-factual politics is sparking pushback among the general electorate, Trump is keeping these polemical excesses alive and kicking, convinced they are effective and will lead to victory as he exults in a style that some see, like the 1930s and 1940s, as linked ideologically to "the end of truth" (Cohen, 2016).

A complete new-comer to electoral politics, Trump's eagerness to assail anyone with insulting put-downs, tout preposterous political claims as obvious truths, and trash-talk high-profile Democratic and Republican politicians for their alleged policy failures over the past generation undoubtedly comes from his shrewd assessment that this rhetorical spectacle is the royal road to free media. Making outlandish claims, and then sustaining efforts to deny, explain or account for them is a Trump tactic to dominate talk shows, nightly news broadcasts, and the writings of most election observers. Any pretense of Trump acting as a decent and fair GOP candidate in civic dedication to the public is now lost in the never-ending effort to answer the question, "Did he really say that, and mean it?"

As Trump rode this wave of free media coverage, he also openly has threatened successful Wall Street bankers, corporate supporters of NAFTA and other free trade pacts, all Mexican immigrants to USA, and professional women in the workplace, to illustrate how he would make American great again. These positions are transforming him into the most favored candidate of many regions of the country, especially those feeling left behind since 1991 . Here, Trump is running to remain the tribune of all the many downwardly mobile, white, working class men and women intent upon punishing all "Establishment" politicians who supposedly have let American become weak, poor, and insignificant in the world since the Reagan era.

Loved by many, but loathed by many more, Trump has sparked truly intense public reactions at home and abroad. Two Belgian creative freelancers, for example, have constructed a website that enables users anywhere to create continuous digital message streams with a radius of 350 meters to render "that territory your personal 'No Trump Zone" < notrumpzone.org/an-open-letter-to-the-world/>. Yet, Trump relentlessly rolls ahead, placing first in the highly divided GOP primaries. With 16 candidates that split the same vote of the party's base between many bad alternatives, the most intense and extreme option, as models of collective choice cycles would suggest, prevailed. Trump himself proved to the most impassioned outsider among the host of more conventional GOP alternatives. He leveraged victory after victory with his no-holds barred reality TV persona, ever adept at constant prevarication, hyperbole, and calumny. While the good intentions these "two Belgian creatives" are still marking multiple spots around the world with 350 square meters of resistance in digital domains, it is too late for the United States of America. The nation already has raced past these electronic warning signs, and entered "the Trump Zone."

Returning to the ironic observations of Rod Serling over 50 years ago, the United States of America appears again to be traveling through this other dimension, "not only of sight and sound but of mind. A journey into a wondrous land of imagination" ("The Twilight Zone," 1960), which loosely defines the expanses of the Trump Zone. Occupying that "middle ground between light and shadow, between science and imagination," Trump's Zone is devoted to "making America great again" by continuously whipping the dark resentment and bitter rage of millions of voters. Their painful losses can be both real and imagined, but Trump's cruel imagery of the America's current condition directly "lies between the pit of man's fear's and the summit of his knowledge" ("The Twilight Zone," 1959) for these blocs of the electorate.

The ethical revulsion and political crisis exposed in tolerating this campaign for the presidency in 2016 even has moved long-time inveterate Republicans who are tolerating repudiating his claims and leaving the GOP to register as "Independent" voters. Of course, the USA has survived through comparable political turmoil during the 1790s, 1820s, 1850s, and 1890s. And, encounters with democracy, lived as a malevolent mash-up of personal threats, complete fabrications, and impossible promises, have sparked many debates in Western political thought for centuries about what is also at stake today about the nature of good governance, the struggles among ruling elites for dominance, levels of trust in normal partisan debate, the purposes of political parties, and who should be entrusted to preserve a republican constitution with a country with still evolving democratic practices.

During a time in which "the one percent" of rich powerful elites are sharply resented by the much poorer " 99 percent" that constitutes the voting public, two New York-based upper-crust party nominees -- Donald J. Trump and Hillary Rodham Clinton -- are brawling daily over the presidency by confessing intensely how they feel the pain 
of the 99 percent. Even though they are both the most unpopular partisan candidates to run for the White House since election pollsters began asking the voting public about each candidate's overall favorable ranking, and both of them are the focus of on-going legal suits, legislative hearings, and media investigations, the vote on November 8 , 2016 will be between a billionaire businessman of dubious capabilities and a millionaire career politico associated with decades of scandal.

One can return, of course, to the ancients for insights into how to govern, but it is more useful only to turn to the nineteenth century to consider how volatile, rare, and advantageous a functioning democracy is. Henry Sumner Maine, for example, in his Popular Government: Four Essays notes a key characteristic about democratic politics that remains all too true today, namely, "of all forms of government, democracy is the most difficult" (1885: 15). A pioneer in comparative jurisprudence, the sociology of law, and organizational theory, Maine was a Victorian educator from Scotland, educated in England, who served in India, and died in France during the hey-day of the British Empire. He astutely regarded what many other voices repeated as dogmatic precepts about modern life and popular government as essentially "unsettled questions," because the centers of royal power, entrenched aristocracy, parliamentary monarchy, military dictatorship, and industrial plutocracy in his time worried openly about whether "popular government" would overturn their rule. If they did, then could popular government succeed?

Predictable elitist political responses during the recent history of the West have undercut the populace by dismissing popular initiatives to share power, because "the people" cannot handle, manage or understand them. More strategic statesmen occasionally did cherry-pick the most popular causes desired by the people to stall popular governance, like accepting a limited political franchise for certain groups of adult males or implementing social insurance schemes for the elderly, permanently disabled or incurably ill, but such civic-minded moves have been few and far between. Otherwise, savvy Old Regime politicos stuck with ideological positions and institutional practices aimed at dissipating the popular forces struggling for "democracy" by reducing them either to political irrelevance or setting them up for criminal incarceration.

Democracy is difficult, and then so too can it be dangerous. But when it works, the widespread benefits for the many far outweigh the narrow rackets of the few. Strangely today, two openly elitist politicians are striving to appear to the American electorate as ordinary, common, and humble as the typical voter, while proposing policies that will preserve longstanding elite privileges by wrapping them up in "making America great again" or affirming "the breaking the glass ceiling for women in politics." Regardless, voting for either one of these two candidates cannot attain either grandiose aspiration except in that "middle ground between light and shadow" that remains "the wondrous land of the imagination."

In the history of the United States of America, Maine's observations come into sharper focus when their full implications become manifest in remarkable elections, such as the ones of 1912 and 2016 (Gould, 2008). Like the current contest, when Bernie Sanders of Vermont declared in the Democratic primaries that Washington must turn to "socialism" for solutions, another Socialist outsider, Eugene V. Debs, made a major play for the White House in 1912. The Republican Party was racked by deep schisms over style, personality, and vision after Theodore Roosevelt declined to campaign for a second elected term (his first came in 1901 as the result of William McKinley's assassination a few months after his reelection), leaving the GOP to nominate William Howard Taft. And, the Democratic Party was tangled up in many traditional tensions between conservative and progressive agendas, sectional frictions, and racial contradictions as Jim Crow America made a joke of most party platform points. It also took the Democrats fourteen ballots to nominate an aloof intellectual elitist, who was a Virginian by birth. This made Woodrow Wilson the first Southerner to have a serious chance at the White House since 1848, but he also was the sitting governor of New Jersey after his successful academic career at Princeton University.

During the 1890s and 1900s, anti-establishment movements in various Populist parties and Progressive associations also arose to challenge the new industrial order growing out of the Second Industrial Revolution (Noble, 1977; and, Chace, 2006) in a manner not unlike the Tea Party or Occupy movement over the past decade. Populist-leaning or Progressive-minded elites had come to hold sway in many cities, counties, and towns, but a truly national regime with aspirations for constructing an industrial democracy, turning to a decisionist presidentialism, and embracing a New Nationalist political culture emerged in difficult fits-and-starts only during the showdown between Woodrow Wilson and Theodore Roosevelt in 1912. An avowed Progressive, Roosevelt quickly revolted against the Republican Party establishment to stand, like "a bull moose," as the candidate of the shaky Progressive Party (Egerton, 2013).

After the realigning election of 1896 (Williams, 2010), the extraordinary electoral race of 1912 arguably left 
the USA very different as the victors started work upon the deep foundations of a much more highly centralized national technocratic order that still is unfolding today. 1912 also featured a stern Socialist agitator seeking "political revolution," a charismatic national hero outcast from his own party, an Establishment GOP nominee intent upon protecting elite interests, and a Democratic nominee, who also was "a first," namely, the first and only presidential candidate with a PhD win the office. With Wilson's victory, and the rise of more Progressive forces in both national parties, this electoral battle also left trenches on the political terrain, which still frame many difficulties of American democracy in twenty-first century. Genuinely popular government has been abandoned to the mercy of professionaltechnical oligarchies in almost all policy domains since 1912 by experts adept at displacing and dissipating deeper democratic practices in the dead-ends of arcane policy discourse and aggravatingly incremental decision-making (Gould, 2008).

The putative worldwide drift toward democracy -- despite the sagas of liberal triumphalism sung worldwide after 1991 -- is neither inevitable nor easy. Rising tides of economic anxiety, sectarian controversy, ethnonationalist fear, and geopolitical conflict in the twenty-first century have pushed many nations toward new mediagenic forms of authoritarianism taking hold in China or Russia. Indeed, the reversal of those post-Cold War currents of liberalization and democratization in the former Soviet Union, Eastern Europe, Southeast Asia or the now lost Arab Spring is ominous. Nonetheless, no change is permanent, and definite turns toward democracy frequently flow from either exhaustion or frustration with other such forms of government. To accept democracy, however, political elites and mass publics must acknowledge the most discomforting reality about democratic governance; namely, the greatest impediment to attaining and maintaining democracy is intrinsic to democracy itself. Despite the warm feelings that self-rule gives so many people in their tummies, all democracies still are states.

As a result, a state apparatus brings the heavy hand of coercion with all of its violent indifference into everyone's life. Yet, such hard facts are not what everyone who shows up to democratic rallies, meetings, and elections, wants to encounter, even though each democratic election usually constitutes intense conflicts short of war in hard struggles to command its capacities. Democracy also purports to serve effectively and justly the interests of all people. Ironically, all states make the same claims. Autocracy and aristocracy, oligarchy and ochloarchy, monarchy and mobocracy also embrace these noble aspirations. Still, a century ago, would-be democrats did push for something less cynical, realizing in the emergent modern industrial economies and societies of the North Atlantic "that power should proceed from below rather from above, and that it is not safe to vest large powers in any branch of government or any group of persons" (Miller, 1915: 213).

It is with this same spirit that most reforms implemented in the name of popular rule since the 1920s, 1960s or 1990s in the United States of America have unfolded, even though all reforms create new winners and losers, gains and losses, identities and differences. While not trusting any branch of government or group of persons, the democratic turn in the USA has never broken large monied interests behind the workings of modern industrial regimes. On the one hand, the best corrective for serious deficiencies in democracy allegedly is greater democracy: more universal suffrage, more direct elections, more intense deliberation, more participation opportunities, more minority rights, etc. Yet, on the other hand, these beliefs do not hold up well in practice, as new electors, more deliberations, added participants, and additional rights holders soon have their agendas co-opted by the oligarchies of authority and interest that democrats in principle oppose. Addressing the difficulties of democracy with still greater democratization, at the same time, only sparks new difficulties for democracy as a system of people's power, because "the people" empowered behind the veil of these good constitutional intentions are never a constant in the equations of power. Indeed, "the People" are unavoidably conflicted, discontinuous, mutable, and variegated, because they are always shifting blocs of peoples, and then so too are the democratic difficulties that ensue.

Although power comes, or appears to come from below, the reluctance by "the demos" to vest power in some definite branch of government or group of persons of "the demos" of democracies also is constrained. With democracy displaced or dissipated, the Progressivist turn in 1912 toward expertise gave trained professional elites the open doors to power, leaving in their wake evermore-impoverished traces of fictive popular rule. Displacing the voice of the people in the noise of constant polling, dissipating true civil devotion into many ritualized civic irrelevancies, and deliberating free individuals with burdensome procedural requirements to allow them participation in electoral politics ends up diluting popular rule.

Similarly, Wilson's pledge in 1914 to keep America "neutral” in the Great War, only to declare war on the Central Powers in the year of his second inauguration three years later led to decades of exceptional presidential authority, which has disfigured American democracy as its popular government has been instrumentalized to serve different 
military goals and geopolitical purposes (Chace, 2005). After 1912, special favor was granted by the formal education, social prestige or hard work demonstrated by professional-technical experts of modern industrial economies. And, whether it means hammering together legislative details, partisan deals, or commercial development, these social forces have produced an technocratic polyarchy structured in a manner that would not be disfavored by republican elitists, like Madison, Jay or Hamilton in The Federalist Papers.

Examining hard questions of democracy and its difficulties against the long horizon of modern governmentality is one facet of Foucault's "critical ontology" of ourselves, which seeks to express "the critique of what we are" as well as "the historical analysis of the limits imposed on us and an experiment with the possibility of going beyond them" (1984:50). Because Foucault (1984: 39) approaches modernity as an "attitude" or an "ethos," it makes sense to explore the conditions of democratization not on the easy terms of liberal democratic theory (Rawls, 1976 and Habermas, 1998). One must take to mapping the difficulty of democracy as a surrender to such technocratic expertise, and the ethos, attitudes, and milieux that integrally are wound up within apparatuses and practices needed for "relating to contemporary reality; a voluntary choice made by certain people; in the end, a way of thinking and feeling; a way, too, of acting and behaving that at one and the same time marks a relation of belonging and presents itself as a task" (1984: 39) in modern democratic governments.

As this analysis suggests, the shift in the United States of America in which these choices were consciously made as a way of belonging, as ways of thinking and feeling, and as the task of producing contemporary reality begins with the remarkable Progressive movement of the 1890s and 1900s. The Republic did move in 1912 toward seeing "promise of American life" (Croly, 1909) in an industrial democracy with a New Nationalism -- lived out as the continuous choices of mass consumption in "lands of desire" (Leach, 1992) at the command of "captains of consciousness" (Ewen, 1976) under the controls of an "America by design" (Noble, 1977) while permanently preparing to mobilize endlessly for war in a world that "must be made safe for democracy" (Wilson, 1917).

To explore how this kind of democracy intertwines its possibilities and prohibitions with theoretical as well as technified governmentality, it must recognize how fully democracy as government of/by/for the people entails a new subjectivity created from/to/through government. The observations in Maine's Popular Government: Four Essays about the embedded difficulties with the democratic impulse requires one to look implicitly at how the "governmentalization of the popular" sculpts, stabilizes and then settles for the economistic consumer subjectivity that now constitutes liberal capitalist democracy. Trump pledges to bring a "business mentality" into policy and sack all of the experts. But this claim is a ruse; he only would seek out other experts in different firms, universities, and think tanks, not unlike Nixon in 1968. It is the satisfaction or dissatisfaction of the consuming public, and those who produce what they consume, that animates the populace and its government. And, no one knows this reality better than the relatively successful owner of glitzy casino resorts.

Moreover, the empowerment of new cadres of administrators, engineers, managers, scientists, and technicians with formal education in what, for example, the USA tagged as "agricultural, mechanical, and other useful arts" (in the Morill Act of 1862 to federally endow new universities to foster such training on the eve of the Second Industrial Revolution) becomes actualized in America's modern industrial formations, commercial culture, and national bureaucracies. Within its matrices of mechanized order, one discovers the life, liberty, and happiness that are the material substrate for sustaining everyday practices for an "industrial democracy" of growing personal consumption and guided free enterprise, which now constitute the sine qua non of liberty, equality, and fraternity (Rose, 1999).

Against this apparent reliance on expertise, The Trump Zone is deeply disturbing. Indeed, it is extraordinary in its use of debasing tabloid style discourse to assail expertise in governance with an angry animus against "the insiders" flowing from "the outsiders" in American democracy. In many ways, Trump is the first presidential candidate grounded in "infoglut" (Andrejevic, 2013), as his vanguard position in the "birther movement" reveals. As he discovered in 2011 during the Internet tizzy over President Obama's "missing" and/or "suppressed" Hawai'ian birth certificate, which Trump asserted would reveal the President to be a Muslim and Kenyan born "non-citizen" (Wickham, 2011: A9), the abundance of information and access to it on mobile wireless devices can lead anyone to believe he or she is "an expert." In the birther networks, the seduction of conspiracy theories, the "bad optics" of numerous uploaded videos, blogs, and news clips, and Trump's claims that own private teams of investigators "could not believe what they were finding" congealed into a "truthiness" that survives today as The Trump Zone's benchmarks of accuracy and reliability. Since many ordinary people can get tremendous access to fast and deep streams of "information" $24 \times 7$, even major news networks pretend that everyman and everywoman is not unlike a professional expert ready with "the facts" to make their own shrewd analysis of anything anytime and anyone with 
some validity and credibility. As Andrejevic notes, however, such travels through Trump Zones of discourse are covered with volatile compounds of market-driven opinion mining, sentiment analysis, and visceral literacy in which the infoglut transmogrifies critiques into imaginative conspiracies that gain traction in daily political dialogues (2013: 111).

No matter how much the ultimate insider Trump actually is, this glut of digital information enables him to push back against other elite experts and insiders that he constantly labels as "losers." While those same established losers look upon the success of his vulgarian style of campaigning in disbelief, Trump's messy modes of marketing "infoglut" truths are upending the pragmatics of American popular politics. By the same token, comparable forces came together during 1912. The newly instituted state-based system of political party primaries, personalized newspaper appeals by "important personalities" for party nominees, and daily silent movie newsreels of the candidates' campaigning as well as the more established use audio recordings by the candidates themselves created another new media ecology that Debs and Roosevelt used to furiously stir the boiling angst of that time, while Taft and Wilson worked with less effectiveness in 1912's informational context. Once again, our current political moment in the United States of America is one that was foreshadowed, in large part, by the electoral contest of 1912.

A new kind of expert and wealthy oligarchy rooted in nationalism, power, knowledge, and wealth, and yet obscured by a veil of ignorance celebrated by liberal apologists, was forged in 1912. It grew bolder and strengthened in 1916 until it gradually developed its own habitus of privileged empowerment in the crises of 1932-1947. Because of World I, the Great Depression, World War II, the Cold War, the rise of fundamentalist Islamic terrorism, and the Great Recession, elements of this social formation -- despite changes in its regional bases, social composition, political agendas, managerial style, and ideological goals -- linger institutionally today, mitigating the progressives' ideological decline as different streams in their movements have steered many of the most decisive policy interventions in the USA for over 100 years.

Some believe rule by "the best and the brightest" crashed in the aftermath of Vietnam. In actuality, one bloc of what now is regarded as the tribunes of "smart power" simply mobilized another winning coalition of putatively even "better and brighter" professional-technical experts to manage democracy's difficulties. Looking at these trends, anyone can see the progressivist/anti-progressive struggles of the USA as a "plutonomy" (Luke, 2011) are not over, whether Trump wins or loses.

Ultimately, generations of progressives gradually have created a uniquely robust habitus (Bourdieu, 1990: 5265; and, Bourdieu, 2000: 138-145) for the position, power, and privilege of progressivism in wings of both major political parties. This habitus underpins a concrete ordering of America's economy and society, which pivots upon, as George Will observes, "government's vastly more ambitious plan to manage" (2013b). Whether it is "the mass media and democracy" (Luke, 1999), "carbon democracy" (Mitchell, 2013) or "war and democracy" (Hardt and Negri, 2005), the multitudes seeking popular governance will accede to an "expertocracy" grounded in technocratic command, control, and communication and/or corporate wheeling-and-dealing, financial leverage, and crass selfpromotion. This social formation works, because its authority molds the democratic subjectivity of the multitudes needed to legitimate permanent managerialism for democracy as everyday governmentality.

As a cohesive social order, this regime has been "progressively inscribed in people's minds" by means of a series of "cultural products" of habitus that produce, and reproduce, their effects via the acculturating force of habitation, ranging from language, values, or taxonomies of cultural classification to the education, religion, or structures of everyday life (Bourdieu, 1984: 471). Such orders of distinction, taste or habit unconsciously do facilitate the acceptance of Progressivist-inspired social boundaries, cultural differences, and political hierarchies, and the Trump Zone is becoming a major new wrinkle in such domains of decision by promising to revitalize America's alleged lost greatness. If elected, neither Clinton nor Trump will forsake expertocratic governance syles, but both of them are running hard against the notoriously self-interested corrupt insiders that supposedly have ruined America since the end of the Cold War.

To understand the Progressive habitus in action, one must understand why "the difficulty of democracy" is how to maintain an intrinsic set of institutional constraints on political practice tied to the form of rule itself. It must be able to morph into an order for enduring many varied alternating rulers, who will leverage this habitus of progressivism as a system for ruling over "the People" rather than unequivocal rule by "the People." In this regard, the vision of Isaiah Berlin (1958) of freedom versus Michel Foucault on governance (1978) typify how "the governmentalization of the popular" rather than strictly "popular government" tacitly has led since 1912 to a guided metrocratic oligarchical republicanism -- under both the Democrats and the Republicans - after the Progressivist 
turn.

Despite the populist turn ignited by Sanders in the Democratic Party to revisit the merits of socialism, and "America First" xenophobia resurrected by Trump from the darkest corners of the GOP in the 1930s, both of these candidates still would tap into the Progressivist ideological habitus at the core of American governance. Even as Trump heckles and hectors Clinton as "Crooked Hilary," and she coyly frames him as "Demented Donald," cohorts of professional-technical experts are hard at work behind both of them. The ultimate riddle, "not only of sight and sound but of mind" in the Trump Zone, is how will one of these two individuals become America's next chief executive, and then lead America's mystifying quasi-democratic/quasi-technocratic republican order, as it has evolved since 1912, far beyond its brittle operational tolerances to cope with the myriad challenges of the twenty-first century in January 2017.

- August 15, 2016

\section{References}

Andrejevic, Mark. 2013. Infoglut: How Too Much Information is Changing the Way We Think and Know. New York: Routledge.

Berlin, Isaiah. 1958/1997. “Two Concepts of Liberty," The Proper Study of Mankind: An Anthology of Essays, ed. Henry Hardy and Robert Hausheer. New York: Farrar Straus Giroux.

Bourdieu, Pierre. 2000. Pascalian Meditations. Stanford: Stanford University Press.

Bourdieu, Pierre. 1990. The Logic of Practice. Stanford: Stanford University Press.

Bourdieu, Pierre. 1984. Distinction: A Social Critique of the Judgement of Taste. Cambridge: Harvard University Press.

Chace, James. 2005. 1912: Roosevelt, Taft, and Debs - The Election that Changed the Country. New York: Siomn \& Schuster.

Cohen, Roger. 2016. “Trump and the End of Truth," New York Times (July 28) [see the International edition: http://www. nytimes.com/2016/07/26/opinion/trump-and-the-end-oftruth.html?_r=0]

Croly, Herbert. 1909. The Promise of American Life. New York: Macmillan.

Dean, Mitchell M. 1999. Government: Power and Rule in Modern Society. London: Sage.

Egerton, Douglas R. 2013. The Wars of Reconstruction: The Brief, Violent History of America's Most Progressive Era. New York: Bloomsbury Press.

Ewen, Stuart. 1976. Captains of Consciousness. New York: McGraw-Hill.

Foucault, Michel. 1984. “What is Enlightenment?” The Foucault Reader, ed. Paul Rabinow. New York: Pantheon.
Foucault, Michel. 1978/1979. “On Governmentality," Ideology and Consciousness, 6 (Autumn), 8-10.

Gould, Lewis L. 2008. Four Hats in the Ring: The 1912 Election and the Birth of Modern American Politics. Lawrence: University Press of Kansas.

Habermas, Juergen. 1998. Between Facts and Norms: A Contribution to a Discourse Theory of Law and Democracy. Cambridge, MA: MIT Press.

Hardt, Michael and Tony Negri. 2005. Multitude: War and Democracy in the Age of Empire. Cambridge, MA: Harvard University Press.

Luke, Timothy W. 2011. "Blow Out, Blow Back, Blow Up, Blow Out: The Plutonomic Politics of Economic Crisis since 2001," Fast Capitalism, 8.2 [www.fastcapitalism.com]

Luke, Timothy W. 1999. Capitalism, Democracy, and Ecology: Departing from Marx. Urbana: University of Illinois Press.

Maine, Sir Henry Sumner. 1885. Popular Government: Four Essays. London: John Murray.

Mitchell, Timothy. 2013. Carbon Democracy: Political Power in the Age of Oil. London: Verso.

Miller, Joseph Dana. 1915. "The Difficulties of Democracy, International Journal of Ethics, Vol. 25, No. 2, (January) 213-225.

Mitchell, Timothy. 2002. Rule of Experts: Egypt, TechnoPolitics, Modernity. Berkeley: University of California Press.

Rawls, John. 1976. A Theory of Justice. Cambridge, MA: Harvard University Press.

Rose, Nikolas. 1999. Powers of Freedom: Reframing Political Thought. Cambridge: Cambridge University Press. 
Wickham, DeWayne. 2011. "Is the Trump Hype over Obama's Birth Newsworthy?” USA Today (April 12): A9.

Will, George. 2013. “The Fed's Applied Progressivism," The St. Louis Post-Dispatch. (September 29).

Williams, R. Hal. 2010. Realigning America: McKinley, Bryan and the Remarkable Election of 1896. Lawrence, KS: University Press of Kansas.
Wlison, Woodrow. 1917. “Text of the President's Address," The New York Times (April 2), 1. [www.newyorktimes.com/ learning/general/onthisday/big/0402.html \#article] 